\title{
River flood risk in Jakarta under scenarios of future change
}

\author{
Yus Budiyono $^{1,2}$, Jeroen C. J. H. Aerts ${ }^{1}$, Daniel Tollenaar ${ }^{3}$, and Philip J. Ward ${ }^{1}$ \\ ${ }^{1}$ Institute for Environmental Studies (IVM), VU University Amsterdam, Amsterdam, the Netherlands \\ ${ }^{2}$ Agency for the Assessment and Application of Technology (BPPT), Jakarta, Indonesia \\ ${ }^{3}$ Deltares, Delft, the Netherlands
}

Correspondence to: Y. Budiyono (yus.budiyono@vu.nl)

Received: 29 May 2015 - Published in Nat. Hazards Earth Syst. Sci. Discuss.: 30 July 2015

Revised: 30 January 2016 - Accepted: 12 February 2016 - Published: 17 March 2016

\begin{abstract}
Given the increasing impacts of flooding in Jakarta, methods for assessing current and future flood risk are required. In this paper, we use the DamagescannerJakarta risk model to project changes in future river flood risk under scenarios of climate change, land subsidence, and land use change. Damagescanner-Jakarta is a simple flood risk model that estimates flood risk in terms of annual expected damage, based on input maps of flood hazard, exposure, and vulnerability. We estimate baseline flood risk at USD 186 million p.a. Combining all future scenarios, we simulate a median increase in risk of $+180 \%$ by 2030 . The single driver with the largest contribution to that increase is land subsidence $(+126 \%)$. We simulated the impacts of climate change by combining two scenarios of sea level rise with simulations of changes in 1-day extreme precipitation totals from five global climate models (GCMs) forced by the four Representative Concentration Pathways (RCPs). The results are highly uncertain; the median change in risk due to climate change alone by 2030 is a decrease by $-46 \%$, but we simulate an increase in risk under 12 of the 40 GCM-RCPsea level rise combinations. Hence, we developed probabilistic risk scenarios to account for this uncertainty. If land use change by 2030 takes places according to the official Jakarta Spatial Plan 2030, risk could be reduced by $12 \%$. However, if land use change in the future continues at the same rate as the last 30 years, large increases in flood risk will take place. Finally, we discuss the relevance of the results for flood risk management in Jakarta.
\end{abstract}

\section{Introduction}

Jakarta, the capital city of Indonesia, suffers from regular floods that cause significant economic damage. For example, the major floods in 2002, 2007, 2013, and 2014 have caused billions of dollars of direct and indirect economic damage (Bappenas, 2007; Ward et al., 2013a; Sagala et al., 2013). Whilst flooding in Jakarta is not a new problem per se (Noorduyn and Verstappen, 1972), the scale of the flood impacts has increased greatly in the last few decades. This increase is related to a large number of drivers, both physical and socio-economic. Physical drivers include land subsidence, low drainage or storage capacity in Jakarta's rivers and canals as a result of being clogged by waste and sediments eroded from upstream, and possibly climate change. Socioeconomic drivers include a rapidly growing population, and land use change causing a growth in economic assets located in potentially flood-prone areas. Extensive overviews of the drivers of increasing flood risk can be found elsewhere (e.g. Budiyono et al., 2015; Caljouw et al., 2005; Steinberg, 2007; Ward et al., 2011b).

As in most parts of the world, flood management in Jakarta has traditionally focused on technical protection measures, in order to lower the probability of the flood hazard through dikes and levees (Texier, 2008). Given the increasing impacts of flooding, and the importance of both physical and socio-economic drivers on risk, recent years have seen a shift towards a more flood-risk-management-based approach in Jakarta (Ward et al., 2013b). Hereby risk is defined as a function of hazard, exposure, and vulnerability, as per the definitions in UNISDR (2011). In this approach, flood risk management measures that address the other elements of risk (exposure and vulnerability) are also considered next to, and in- 
deed in combination with, traditional hazard-reducing measures. This can be seen in ongoing and planned flood risk management activities, such as the planned Garuda Project (Kementerian Koordinator Bidang Perekonomian, 2014), as part of the National Capital Integrated Coastal Development project, as well as the Jakarta Spatial Plan 2030 (Rencana Tata Ruang Wilayah 2030, 2012), which specifically mentions the integration of flood control and zoning with spatial planning measures. Flood risk is also identified in the Law No. 24/2007 as well as its description in Government Regulation No. 21/2008. The implementation of the latter is documented in the National Action Plan for Disaster Risk Reduction (NAP-DRR) 2010-2012 at country scale by the National Development Planning Agency (Bappenas, 2010) and the United Nations Development Programme.

The flood risk approach can also be seen in scientific developments related to flooding in Jakarta. For example, using global models, Hanson et al. (2011) examined the exposure of people and assets to coastal flooding in 136 port cities worldwide, including Jakarta, and using a similar approach, Hallegatte et al. (2013) estimated flood risk in terms of annual expected damages in those cities. More specifically for Jakarta, Ward et al. (2011b) assessed the potential exposure of assets to coastal flooding in Jakarta, but did not carry out a full flood risk analysis.

The first city-scale quantitative flood risk assessment in Jakarta was that of Budiyono et al. (2015), who developed a river flood risk assessment model (Damagescanner-Jakarta) to assess current river flood risk. However, when planning adaptation measures and strategies, it is also vital to know how risk will develop in the future. Future flood risk in Jakarta is complicated, since it will depend on the interplay of the myriad of physical and socio-economic drivers of risk. For coastal flooding, the global-scale studies of Hanson et al. (2011) and Hallegatte et al. (2013) examined the potential influence of changes in climate, land subsidence, and population growth on flood exposure and risk. However, they focus only on coastal flooding, using rough estimates from global models, and neither on river floods nor the projection in the future.

The aim of this paper, therefore, is to further apply and develop the Damagescanner-Jakarta risk model from Budiyono et al. (2015) to project possible future changes in river flood risk in Jakarta as a result of climate change, land subsidence, and land use change. Using these simulations, we can examine the individual influence of these risk drivers to overall changes in flood risk. Given the limited amount of input data for the future scenarios of subsidence and land use change, this paper is not intended to provide a full uncertainty assessment. For each driver of risk, we use the best available data to develop future scenarios, meaning that more scenarios are available for some drivers (e.g. climate change) than others (e.g. land subsidence and land use change). Therefore, the results should be interpreted as first-order estimates of the potential order of magnitude of the future changes in risk.

\section{Method}

In this study, we use Damagescanner-Jakarta, a flood risk model for Jakarta developed by Budiyono et al. (2015) in the Python programming language. Damagescanner-Jakarta estimates flood risk as a function of hazard, exposure, and vulnerability. The model is explained in detail in Budiyono et al. (2015). In brief, the model has a horizontal resolution of $50 \mathrm{~m} \times 50 \mathrm{~m}$, and works by combining maps of hazard and exposure with a depth-damage function to represent vulnerability. For each grid cell, the model identifies the depth of inundation found in the flood hazard map. For this grid cell, it then identifies the land use class and the associated value of maximum damage for this class. The model then uses the depth-damage function for the land use class in question, to identify what proportion of the maximum damage would occur for the inundation depth in that cell. By combining these three elements, the model estimates the direct economic damage. This procedure is carried out for floods of several return periods between 2 and 100 years. Finally the expected annual damage is calculated as the area under the exceedance probability-loss (risk) curve, whereby the area is estimated using a trapezoidal approximation (e.g. Meyer et al., 2009).

In Budiyono et al. (2015), the model was set up to simulate risk under current conditions. Here, we further improve the model to simulate future flood risk, by including projections of physical and socio-economic change. These are incorporated into the model by changing the input data representing the three elements of flood risk, as presented in the framework of analysis in Fig. 1. In the following sections, the data used to represent hazard, exposure, and vulnerability are described.

\subsection{Hazard}

Flood hazard is represented by maps showing inundation depth and extent for several return periods (1, 2, 5, 10, 25, 50 , and 100 years). To simulate flood hazard, we used the SOBEK Hydrology Suite, which is a model suite combining a Sacramento hydrological model and a 1-D/2-D hydraulics model (Deltares, 2014). More information on the model and its use in Damagescanner-Jakarta can be found in Budiyono et al. (2015). The model for Jakarta was developed during the flood hazard mapping project and the Flood Management Information System project (Deltares et al., 2012), by Deltares, National Bureau for Meteorology (BMKG), Research Center for Water Resources (Pusair) and Jakarta Office of Public Works (DPU-DKI). For baseline conditions, we used the hydraulic schematization resulting from field measurements in 2012.

In this study, we also simulated inundation maps (for each return period) for different future scenarios of climate change and land subsidence. To simulate impacts from cli- 


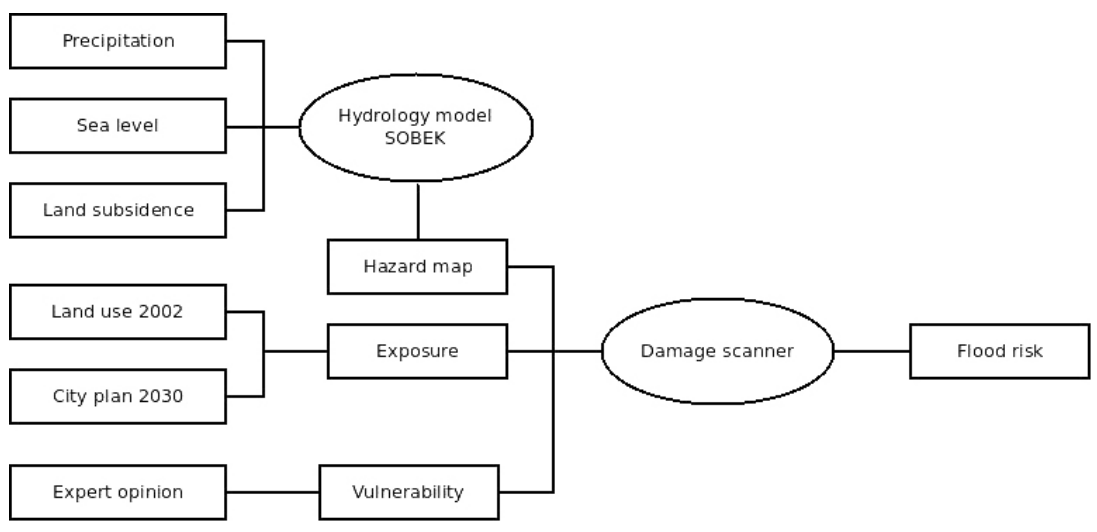

Figure 1. Framework of analysis.

mate change, we forced the model with changes in two factors: precipitation intensity and sea level rise.

Uncertainty in future changes in precipitation, and precipitation intensity, is known to be very high in the region, as discussed in Sect. 4.1. Hence, we estimated change in precipitation intensity using output data from a large range of global climate models (GCMs) and Representative Concentration Pathways (RCPs). To do this, we used bias-corrected daily data on precipitation from five GCMs, obtained from the ISI-MIP project (Inter-Sectoral Impact Model Intercomparison Project) (Hempel et al., 2013). These bias-corrected data are available at a horizontal resolution of $0.5^{\circ} \times 0.5^{\circ}$. The bias-correction method is described in detail by Hempel et al. (2013). In brief, they modified the daily variability of the simulated precipitation data around their monthly means, in order to match daily precipitation variability in the EUWATCH baseline reanalysis data set (Weedon et al., 2011) for the period 1960-1999. Monthly variability and mean were corrected using a constant multiplicative correction factor, which corrected for long-term differences between simulated monthly mean precipitation and mean monthly precipitation from the EU-WATCH baseline reanalysis data set.

These downscaled future climate data were used for five GCMs, namely GFDL-ESM2M, HadGEM2-ES, IPSLCM5A-LR, MIROC-ESM-CHEM, and NorESM1-M, and for the following Representative Concentration Pathway (RCP) scenarios: RCP2.6, RCP4.5, RCP6.0, and RCP8.5. Thus, we used 20 GCM-RCP combinations in total. We calculated change factors in daily precipitation between the baseline climate data set and each GCM-RCP combination, for each of the return periods used in this study. The extrapolation to the different return periods is carried out by fitting the Gumbel distribution to the time series of annual maximum precipitation, whereby the Langbein correction (Langbein, 1949) is applied for return periods lower than 10 years. We carried out this statistical process for each of the GCMRCP combinations for two time periods, namely 2010-2049 and 2040-2079. These time periods are used in the paper to represent climate conditions in 2030 and 2050, respectively. Finally, these change factors were applied to the standard input of the SOBEK model under current conditions, which is based on gauged precipitation data at 29 stations.

In the SOBEK model, sea level is used as a boundary condition at the river-sea interface. Therefore, we used two simple scenarios of sea level rise between 2010-2030 and 2010 2050, and added these to the SOBEK input baseline sea level for 2010. These low and high scenarios represent the likely range in global sea level rise projections of the IPCCs Fifth Assessment Report (AR5) (IPCC, 2013, Table AII7.7) average across all four RCPs. The scenarios represent increases in sea level of 6 and $11 \mathrm{~cm}$ respectively for the period 2010 2030 , and 14 and $24 \mathrm{~cm}$ respectively for the period 2010 2050.

Finally, we also produced hazard maps showing the magnitude of continued land subsidence. This was done by subtracting projections of future subsidence from the digital elevation model (DEM) used in SOBEK (Deltares et al., 2012; Tollenaar et al., 2013). The DEM has a horizontal resolution of $50 \mathrm{~m} \times 50 \mathrm{~m}$. In SOBEK, the original DEM is replaced by the new DEM (including future subsidence), and the hydrological-hydraulic simulations are repeated. This results in new flood hazard maps showing the flood inundation and extent under the land subsidence scenario, which are then used as input to the Damagescanner-Jakarta model. A map showing the spatial distribution of the projected land subsidence between 2012 and 2025 used in our model set-up is shown in Fig. 2. We used a hypothetical scenario of land subsidence, in which the current rate of subsidence (Abidin et al., 2011) continues at the same rate, and ultimately stops in the year 2025. This current rate of subsidence ranges from 1 to $15 \mathrm{~cm}$ per year across different parts of the city; the resulting spatial distribution of land subsidence over our study period is shown in Fig. 2. The linear trend in future subsidence was decided in close collaboration with the National Bureau of Meteorology (BMKG) and Jakarta Office of Public Works (DPU-DKI). The linear rate of subsidence is based 


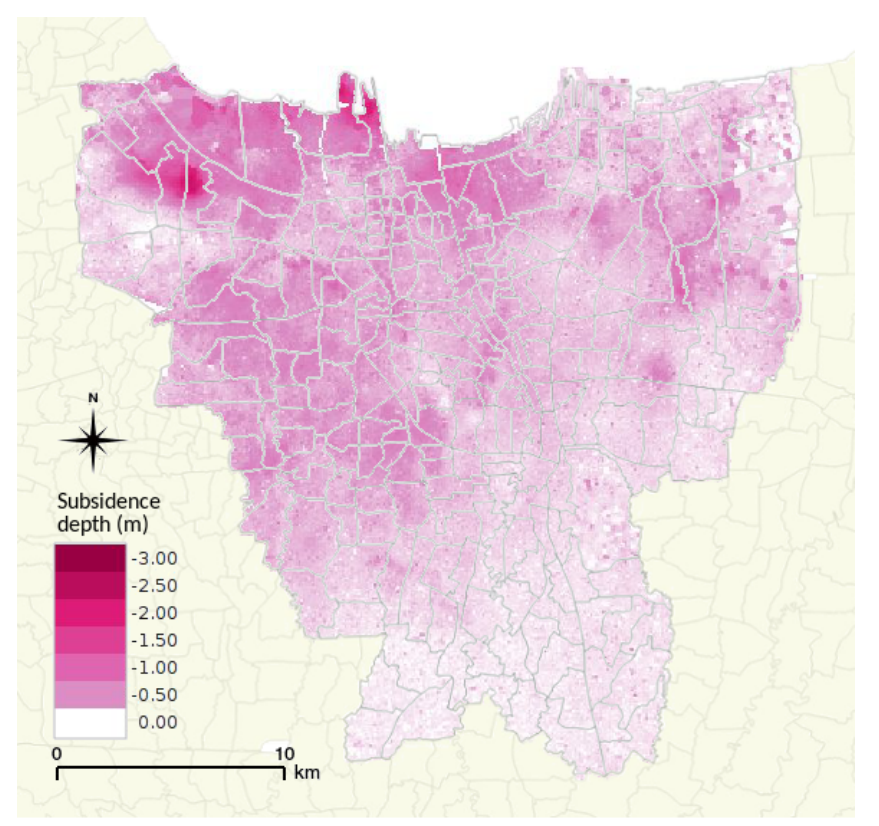

Figure 2. Spatial distribution of projected total land subsidence over the period 2012-2025.

on investigations in several other cities over longer time periods, for example Tokyo for 60 years (Endo et al., 2001), Tokyo lowlands for 20 years (Aichi, 2008), and Bangkok for 20 years (Phien-wej et al., 2006). In several cities, it has been shown that land subsidence can be reduced rather rapidly once groundwater extraction is reduced. For example, in Tokyo the government implemented a gradual groundwater extraction policy for 13 years by preventing the creation of new wells and regulating groundwater extraction in the central districts of Tokyo to an absolute minimum (Tokunaga, 2008). As a result, groundwater potential recovered quickly, particularly due to high recharge rates in the region, and the land subsidence stopped in several years. In March 2015, the Ministry of Public Works (PU) in Indonesia issued the "100-0-100" sanitation policy (Direktorat Jenderal Cipta Karya, 2015), which means that the government aims to provide $100 \%$ of water supply needed by Jakarta by 2019 . If the policy target is achieved in time, it is the expectation that land subsidence would reduce quickly after 2019, and hence, the assumption to continue land subsidence until 2025 in the model.

As was the case in Budiyono et al. (2015), we assume that no flood damage occurs at a return period of 1 year. Hence, simulated flood depths at 1-year return period are subtracted from simulated flood depths for higher return periods. This was carried out in order to represent an assumption of zero damage at bankfull discharge (e.g. Ward et al., 2011a; Winsemius et al., 2013). The flood hazard maps generated by SOBEK represent a situation in which the flood management system in place is operating under normal conditions, and cannot account for system failures or those caused by a lack of maintenance.

\subsection{Exposure}

In Damagescanner-Jakarta, exposure is represented through land use maps, whereby each land use class has an associated maximum economic exposure value (in USD per hectare). In our earlier study (Budiyono et al., 2015) we used the land use map 2002 (DTR DKI, 2007) to represent baseline conditions. However, we now have a more up-to-date land use map available, namely the land use map 2009, which was issued by the Office of City Planning, Jakarta (Rencana Tata Ruang Wilayah 2030, 2012). Hence, for this paper, we used this more up-to-date land use map 2009 to represent baseline land use.

The land use map 2009 contains a larger number of classes than the land use map 2002. Hence, the land use map 2009 was first reclassed to show the same land use classes as the land use map 2002; the reclassification was carried out as per Table 1 . This reclassification was necessary because the estimates of maximum economic exposure value and the depthdamage function used in Damagescanner-Jakarta are based on the original land use classes from the land use map 2002.

For future land use, we took two approaches to estimate the future influence of land use change in 2030. Firstly, we developed an idealized land use scenario for 2030, based on the official Jakarta Spatial Plan 2030 (Rencana Tata Ruang Wilayah 2030, 2012), which was recently approved by the lower House of Representatives, Jakarta. The Spatial Plan 2030 contains 12 land use classes, which is the same number of classes as the land use map 2002. However, three of the land use classes in the Spatial Plan 2030 pertain to the planned new reclamation islands, which should not be affected by river flooding. Hence, three of the land use classes present in the land use map 2002 are not used in the Spatial Plan 2030. Note also that the Spatial Plan represents an idealized situation, and as a result it shows much more homogenous patterns of land use than the land use map 2009 used for the baseline conditions. Therefore, we represented the future change in risk due to land use change as follows. Firstly, we reclassed several land use classes to derive similarities of land use between the current land use map and the Spatial Plan 2030 (see notes accompanying Table 2). Then, using GIS analysis we calculated the total area of each land use class in 2009 and 2030, as shown in Table 2. From this, we were able to derive factors showing the change in the area of each land use category. This was used in the damage calculations to estimate the change in risk per land use category between the baseline and future scenarios. For example, the total area of land use class "Industry and warehouse" increases from 7.06 to $8.87 \%$ (an increase of ca. 26\%). Hence, the annual expected damage associated with this land use class was increased by $26 \%$ in the future scenario compared to the baseline scenario. Whilst this map represents an ideal- 
Table 1. Reclassification of 21 land use classes from the land use map 2009 to the 12 land use classes of the land use map 2002.

\begin{tabular}{lll}
\hline \multirow{2}{*}{ No. } & \multicolumn{2}{c}{ Land use names } \\
\cline { 2 - 3 } & 2002 & 2009 \\
\hline 1 & Agriculture and open space & Wetland agriculture, dryland agriculture, open space, unused land \\
2 & Commercial and business & Healthcare, others, commercial, market \\
3 & Education and public facility & Education \\
4 & Forestry & n/a \\
5 & Government facility & Government facility \\
6 & High density urban kampung & Urban kampung, place of worship \\
7 & Industry and warehouse & Service station, manufacture, industrial place, warehouse, animal husbandry \\
8 & Low density urban kampung & n/a \\
9 & Park and cemetery & Cemetery \\
10 & Planned house & Planned house \\
11 & Swamp river and pond & Pond fishery \\
12 & Transportation facility & Transportation facility \\
\hline
\end{tabular}

Table 2. Area per land use class compared to total area of Jakarta (\%) for the baseline land use map 2009 and the Spatial Plan 2030. Several of the original land use classes were reclassed as per the notes under the table.

\begin{tabular}{llcc}
\hline No. & Land use class name & 2009 & 2030 \\
\hline 1 & Agriculture and open space $^{\mathrm{a}}$ & 7.48 & 14.17 \\
2 & Residential $^{\mathrm{b}}$ & 61.67 & 57.61 \\
3 & Swamp river and pond & 7.66 & 1.00 \\
4 & Industry and warehouse & 6.47 & 8.87 \\
5 & Commercial and business & 10.33 & 16.46 \\
6 & Government facility & 4.01 & 1.98 \\
7 & Forestry & 0.00 & 0.33 \\
\hline & Total & 100.00 & 100.00 \\
\hline
\end{tabular}

a Merge of "Agriculture" and "Agriculture and open space" in both the baseline land use map and Spatial Plan 2030.

b Merge of "High density urban kampung", "Low density urban kampung" and "Planned house" in baseline land use map; and merge of "Residential" and "Residential with greenery" in Spatial Plan 2030.

c Merge of "Government facility", "Education and public facility", and

"Transportation facility" in baseline land use map; merge of "Government facility", and "Transportation facility in Spatial Plan 2030, while land use class "Education and public facility" does not exist.

ized scenario, assuming that all of the plan is implemented, it is useful to use in this study since it is the map used in official studies in Jakarta. Each land use class is assigned a value of economic exposure per hectare (Table 3 ). These values were derived via a series of expert meetings and a workshop, as described in detail in Budiyono et al. (2015), and as described briefly in Sect. 2.3. For land use classes that are consistent for both land use maps, values are taken directly from Budiyono et al. (2015). For land use classes where reclassifications were required as described above, exposure values were derived by area-weighted averaging. For example, the maximum value of land use class "Residential" in the land use map 2030 results from the average of two classes, weighted by spatial percentage of land use classes "High density urban
Table 3. Maximum economic exposure values per land use class for land use map 2030, using an exchange rate of USD $1=$ IDR 9654.

\begin{tabular}{llr}
\hline No & Land use class name & $\begin{array}{r}\text { New maximum } \\
\text { economic exposure } \\
\text { value (thousand } \\
\text { USD per hectare) }\end{array}$ \\
\hline 1 & Government facility $^{\mathrm{a}}$ & 301.0 \\
2 & Forestry $_{3}$ & 10.4 \\
4 & Industry and warehouse $^{\text {Commercial and business }}$ & 517.9 \\
5 & Residential $^{\text {b }}$ & 517.9 \\
6 & Residential with greenery $^{\mathrm{c}}$ & 150.6 \\
7 & Agriculture & 341.8 \\
8 & Swamp river and pond $_{9}$ & 1.6 \\
9 & Agriculture and open space & 3.8 \\
\hline
\end{tabular}

a Area-weighted average of land use classes "Education and public facility" and "Government facility" in land use map 2002.

b Area-weighted average of land use classes "High density urban kampung" and "Low density urban kampung" in land use map 2002.

${ }^{\text {c }}$ Land use class "Planned house" in land use map 2002.

kampung" and "Low density urban kampung" in the baseline land use map (detail in Table 3).

Secondly, because the Spatial Plan 2030 represents an idealized situation, we also developed a simple method to assess how risk may change in the future if this idealized plan is not achieved. To do this we calculated flood risk using Damagescanner-Jakarta using the land use maps 1980, 1995, 2002, and 2009, all reclassed to the same land use classes as used in the land use map 2002. We then fit a second-order polynomial fit $\left(r^{2}=0.837\right)$ to these flood risk calculations, and used the resulting regression equation to estimate risk in 2030. Hence, this gives a first-order estimate of how future risk may develop in the future if land use change continues at the same rate as over the period 1980-2009. Unfortunately, 
no land use simulation models are available to specifically simulate future land use in Jakarta.

\subsection{Vulnerability}

The third element of the risk framework is vulnerability. In this paper, we adopt the definition of UNISDR (2011), that vulnerability is "the characteristics and circumstances of a community, system or asset that make it susceptible to the damaging effects of a hazard". In DamagescannerJakarta, vulnerability is represented by depth-damage functions (Merz et al., 2010), which show the fraction of the maximum economic exposure value per land use type that would actually result in damage for different inundation depths (see Fig. 4). In reality, these functions only represent physical vulnerability, but not social vulnerability, i.e. the sensitivity of populations to natural hazards and their ability to respond to and recover from their impacts (e.g. Cutter and Finch, 2008; Cutter et al., 2013; Gain et al., 2015). We therefore use the term depth-damage functions throughout the rest of this paper, to avoid confusion.

The depth-damage functions for Jakarta were derived in a previous study (Budiyono et al., 2015), for each of the land use classes in the land use map 2002. These synthetic depthdamage functions were developed through a series of expert meetings and a workshop, following the fuzzy cognitive mapping method (Groumpos, 2010; Stach et al., 2010). The process consisted of two rounds. First, a series of four expert meetings was held employing nine stakeholders in order to derive preliminary maximum economic exposure values and depth-damage functions. Secondly, a 1-day workshop was held with a larger group of different stakeholders in order to validate, and where necessary to improve the initial values and functions. The resulting depth-damage functions are shown in Fig. 4. For further details on the method used to derive the depth-damage functions, including the participants of the expert meetings and workshop, we refer the reader to Budiyono et al. (2015). The same depth-damage functions were used for the baseline scenario and 2030, since no data were available on potential changes in the curves over that time (see Sect. 4.3).

\section{Results}

This section is split into three subsections. Firstly, we describe the flood risk results under baseline conditions in comparison to past results reported in Budiyono et al. (2015) to show the change resulting from the new model schematization and the newly operational flood protection measures. Secondly, we show the potential impacts of climate change on extreme precipitation, one of the drivers of risk change discussed in this paper. Thirdly, we show the potential changes in flood risk between the baseline situation and the future, based on the various future scenarios. We examine both the individual and combined influence of the different drivers on flood risk.

\subsection{Flood risk under baseline conditions}

In this study, we ran Damagescanner as described in Sect. 2. The resulting flood risk under baseline conditions is USD 186 million p.a. Figure 3 shows the distribution of flood risk compared to a modelled flood hazard map for a return period of 100 years. This number is significantly lower than our past result as presented in Budiyono et al. (2015), in which flood risk was estimated to be USD 321 million p.a. There are several reasons for this. Firstly, as explained in Sect. 2.2, in the current study we use a more up-to-date land use map to represent baseline exposure. If we use the same land use map as was used in Budiyono et al. (2015), the estimate of baseline risk using the new model set-up is USD 143 million p.a. The lower flood risk estimate in the current paper compared to our previous estimate is due to changes that have been carried out in the hydraulic system in Jakarta, which have been included in the revised schematization of the hydrological and hydraulic model used for this paper. The version of the hazard model used in Budiyono et al. (2015) used a hydraulic schematization based on the situation in 2007. In the current paper, we used an updated version of the model in which the hydraulic schematization has been updated to include flood protection measures, including flood gates and weirs that have been implemented between 2007 and 2013. Moreover, the revised version of the model has a more accurate representation of those flood protection measures that were already in place in 2007. The most important single change in the hydrological and hydraulic situation since 2007 has been the completion of the East Flood Canal (Banjir Kanal Timur). This canal diverts flood waters away from the eastern side of the city. It was not included in the former schematization of SOBEK, but is included in the new schematization used in this paper. Comparing the flood hazard maps for a given return period based on the 2007 and 2013 schematizations shows that the simulated flood extent in the eastern half of the city has indeed decreased. For example, in Fig. 5 we show the differences in inundation depth between 2007 and 2013; in the eastern half of the city, the flood extent has decreased by $27 \%$ in terms of width or by $34 \%$ in terms of volume.

As a result of the major changes in the hydrological and hydraulic situation since 2007 , it is difficult to directly compare our modelled flood damages directly with reported damages for floods that occurred before that time. Reported damages for the 2007 flood are available from Bappenas, namely USD 890 million. This flood had a return period of ca. 50 years. Our simulated damages for a 50-year return period flood using the new model schematization and land use map 2009 are USD 579 million, i.e. $35 \%$ lower than the reported losses in 2007 . This seems reasonable given the afore- 


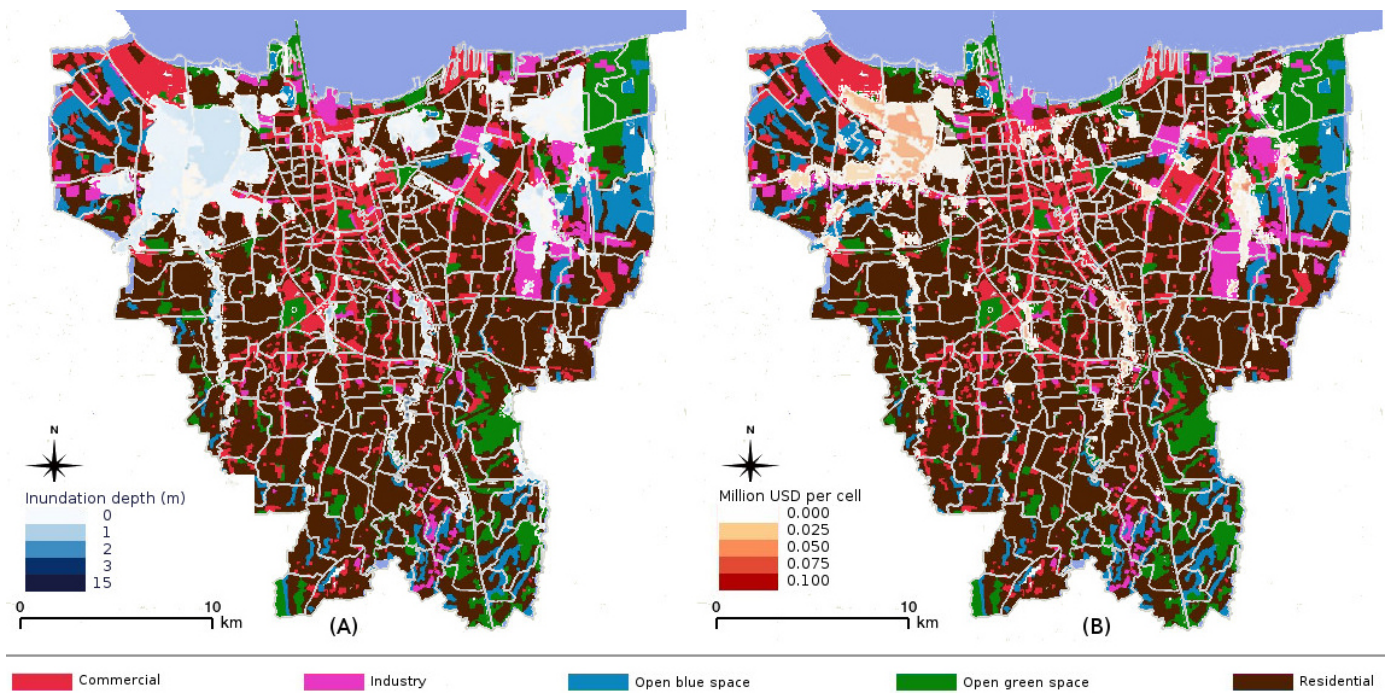

Figure 3. Flood hazard map for a return period of 100 years in current conditions (a); and annual expected damage (b). The background is land use map 2009, reclassed into five land use classes found in the three previous land use maps.

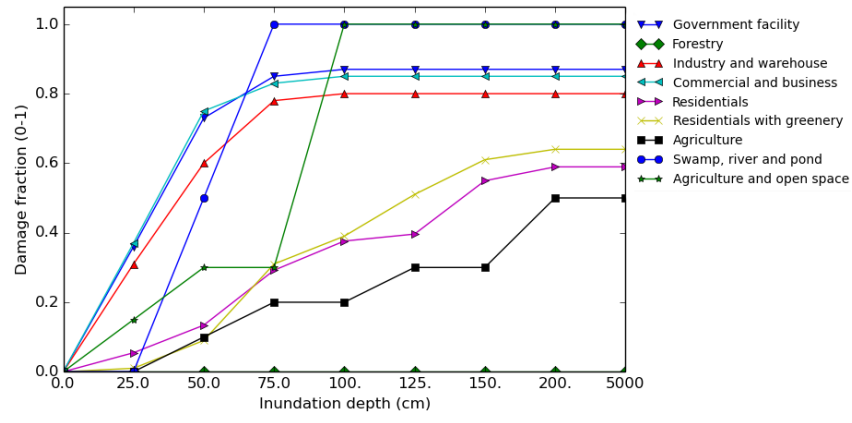

Figure 4. Depth-damage functions used in this study for each land use class.

mentioned changes in the hydrological and hydraulic situation since that time.

The reliability of the new 2013 flood maps has also been compared with empirical flood maps produced by the National Disaster Management Office (BNPB). These maps show which village administration units (Kelurahan) in Jakarta actually suffered from inundation during the 2007 and 2013 flood events (Fig. 6). We can see that the spatial pattern in the western half remains fairly similar, whilst far fewer Kelurahan were reported as suffering from inundation during the 2013 flood in the eastern part. It should be noted that the return periods of the floods in 2007 and 2013 are not exactly the same; the former is estimated to have a return period of ca. 50 years, compared to 30 years in the latter. Hence, the figure is only intended to demonstrate the fact that there appears to be an overall agreement between the 2013 modelling results and the government flooding maps showing smaller inundation areas in the eastern parts as compared

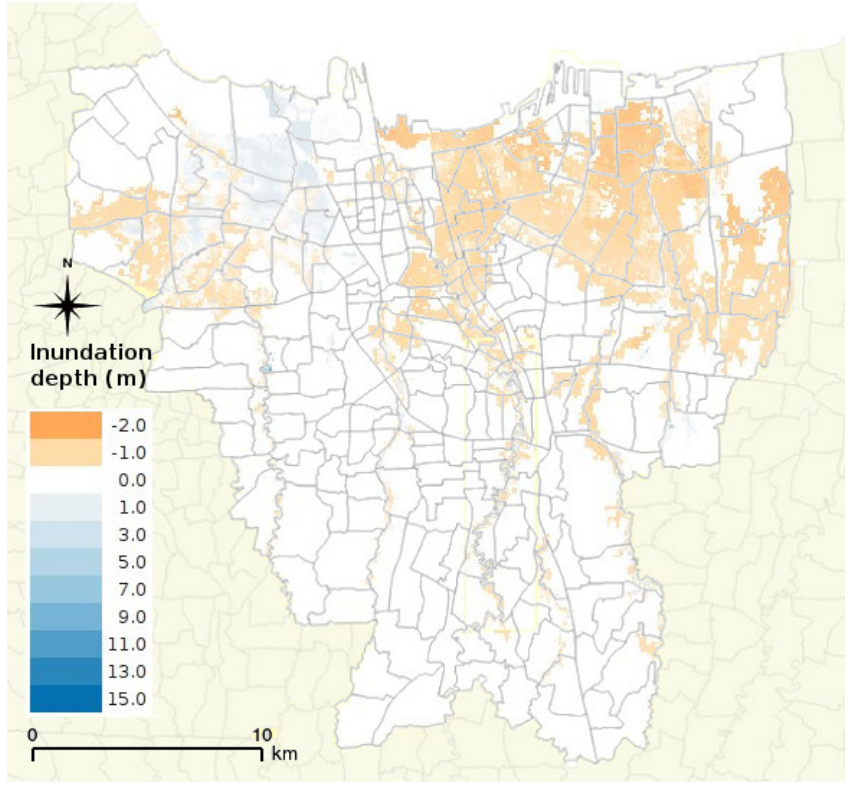

Figure 5. Change in inundation depth for a return period of 100 years in the flood hazard maps based on the SOBEK schematization of 2013 compared to that of 2007.

to previous research. This explains our lower risk estimates compared to Budiyono et al. (2015).

Finally, the changes in the inundation depths are also partly due to further modifications of the SOBEK schematization in terms of its hydraulics. Namely, the Saint-Venant equations have been implemented on more detailed dimensions of stream fractions, which produces finer 1-D overtopping and a more disperse but shallower 2-D floodplain. 


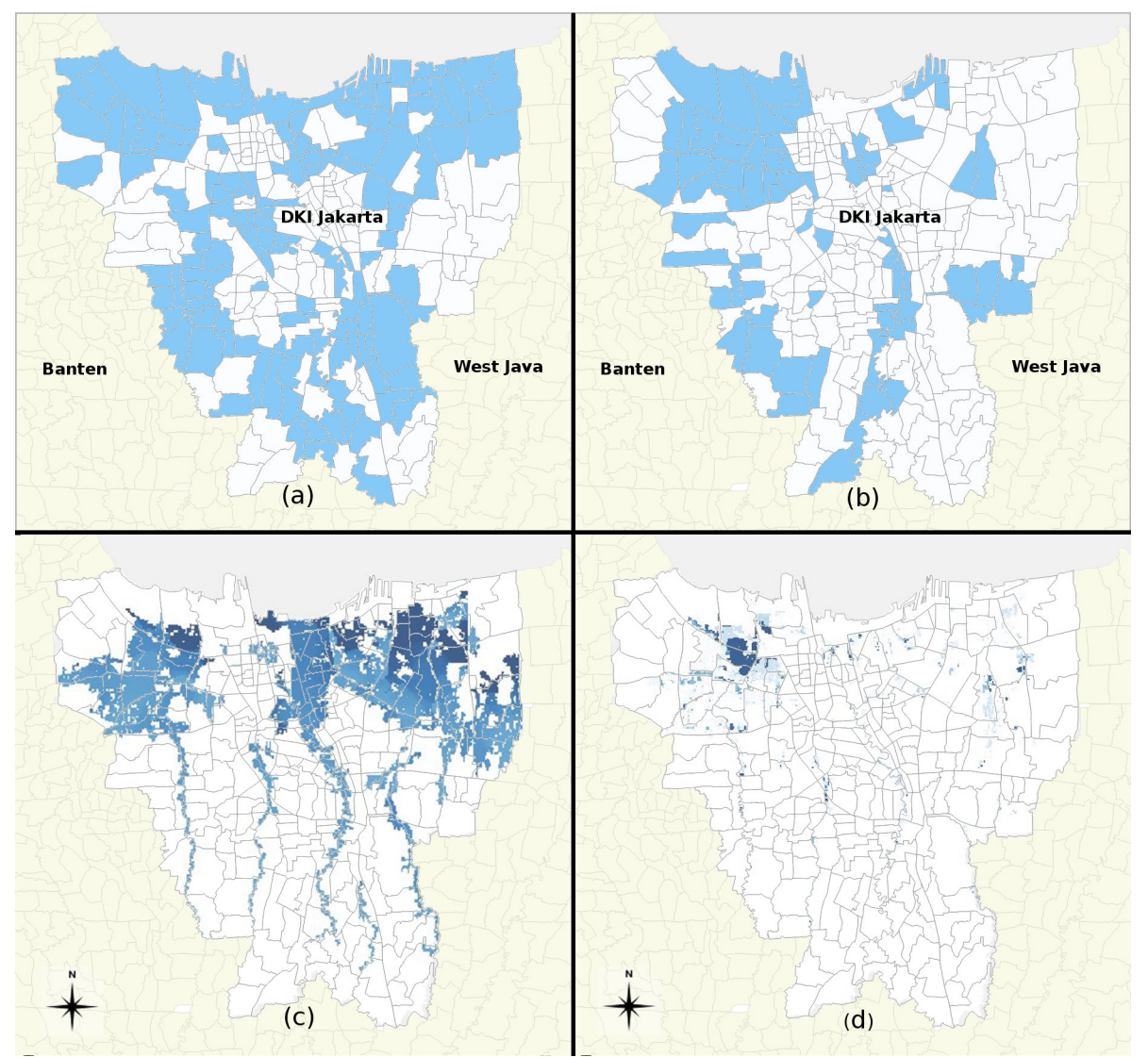

Figure 6. Maps showing Kelurahan (village administration units) in which part of the village administration unit was reported to be inundated in the (a) 2007 and (b) 2013 floods. These maps were reported to the National Disaster Management Office (BNPB) by the village administrator. The estimated return periods of the flood events in 2007 and 2013 are 50 and 30 respectively. Below, the inundation maps from the SOBEK model are shown, based on (c) 2007 schematization and a return period of 50 years, and (d) 2013 schematization and a return period of 25 years.

\subsection{Potential impacts of climate change on extreme precipitation}

As described in Sect. 2.1, we estimated changes in the magnitude of 1-day precipitation sums for the different return periods used in this study, based on data from five GCMs and four RCPs, i.e. 20 GCM-RCP combinations. In Fig. 7, we present precipitation factors that show changes in extreme 1day precipitation for different return periods, whereby a factor " 1 " represents the extreme 1-day precipitation under baseline conditions. The results for 2030 and 2050 are shown in Fig. 7.

The results show that the impacts of climate change on extreme 1-day precipitation in 2030 and 2050 are highly uncertain. The median values of both 2030 and 2050 show lower 1-day precipitation sums by ca. $20 \%$ (2030) and $19 \%$ (2050) compared to baseline conditions, with very little variation between the different return periods (standard deviations 0.8 and $1.2 \%$ in the sequential years). However, whilst the median values indicate a decrease, the uncertainty is extremely large, as reflected by the large range in values, and the large
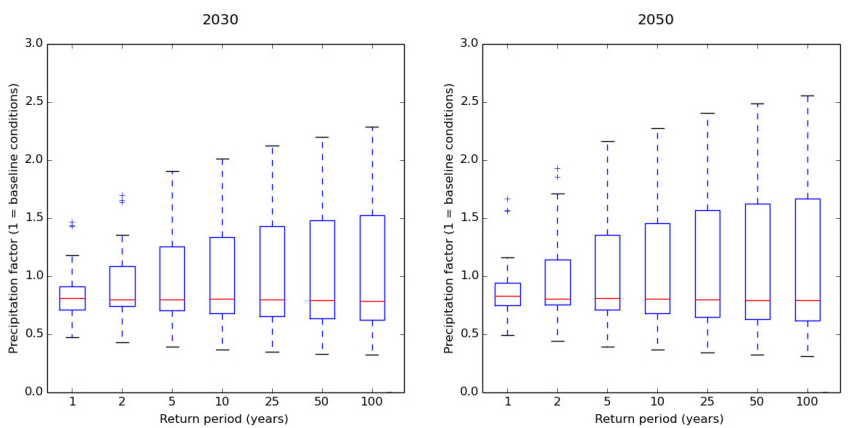

Figure 7. Box-and-whisker plots showing the distributions of precipitation factors (where a factor of " 1 " equals baseline conditions) for extreme 1-day precipitation for several return periods, ranging from 1 to 100 years. The results are shown for 2030 and 2050. The results are based on five GCMs and four RCPs. The box plots show the median values for the $20 \mathrm{GCM}-\mathrm{RCP}$ combinations (red lines), the 25th and 75th percentiles (top and bottom of boxes), and the range (whiskers). Outliers as shown as "+". 
range between the 25th and 75th percentiles. Even the sign of the change is highly uncertain. Moreover, Fig. 7 also shows that this spread in the distributions of change in 1-day precipitation sums increases as the return period increases, reflecting even greater uncertainty in changes in the precipitation events with a longer return period.

In terms of the median values, we found little difference in the precipitation change factors between the different RCPs (Table 4). For 2030 these ranged from 0.76 for RCP4.5 to 0.85 for RCP8.5, and for 2050 they ranged from 0.79 for RCP2.6 to 0.96 for RCP8.5. Across the five different GCMs, the standard deviation in these precipitation change factors is large (Table 4), showing the large uncertainty of how this variable may change in the future.

\subsection{Impacts of future changes in individual risk drivers on flood risk}

In this section, we describe the potential changes in flood risk between the baseline estimate of USD 186 million p.a., and the future, for each of the risk drivers separately.

\subsubsection{Climate change}

Firstly, we show the potential influence of climate change only on future flood risk compared to baseline flood risk. The results are shown in Table 5. Here, we show the future risk (in 2030 and 2050) for each of the different combinations of precipitation intensity (represented by the RCP scenarios) and sea level rise (low and high scenarios). The median and standard deviation of the results across the five GCMs are shown for each combination of RCP and sea level rise scenario. From these results, there is no clear signal of change in future flood risk as a result of climate change alone.

For 2030, under the low sea level rise scenario, the median risk is in fact lower than for the baseline (USD 186 million p.a.) for all RCPs. However, the standard deviation is large. Under the high sea level rise scenario, the median risk is higher than baseline for two RCPs, and lower for the other two RCPs; again the standard deviation between GCMs is large. For 2050, the results generally show slightly higher risk compared to 2030, under both sea level rise scenarios.

Across all 40 combinations of GCMs, RCPs, and sea level rise scenarios (five GCMs $\times$ four RCPs $\times$ two sea level rise scenarios), the risk estimates range from USD 24 to 380 million p.a. for 2030, and USD 34 to 517 million p.a. for 2050. For 2030, a decrease in risk compared to baseline was simulated in 28 of these combinations, with an increase under the other 12 combinations. For 2050, a decrease was simulated in 22 of the combinations, with an increase in the other 18 combinations. The wide amplitude of flood risk and the variations of GCM-RCP combinations quantitatively display uncertainty of climate projection and the resulting flood risk; see Sects. 4.1 and 4.2 for further discussion.
Table 4. Median and standard deviation of precipitation multiplication factor between the five GCMs for each RCP scenario in 2030 and 2050 .

\begin{tabular}{|c|c|c|c|}
\hline & & Median & $\begin{array}{l}\text { Standard } \\
\text { deviation }\end{array}$ \\
\hline \multirow{4}{*}{ ণ্ণ } & RCP2.6 & 0.79 & 0.33 \\
\hline & RCP4.5 & 0.76 & 0.47 \\
\hline & RCP6.0 & 0.79 & 0.51 \\
\hline & RCP8.5 & 0.85 & 0.49 \\
\hline \multirow{4}{*}{ 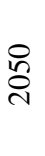 } & RCP2.6 & 0.79 & 0.32 \\
\hline & RCP4.5 & 0.82 & 0.48 \\
\hline & RCP6.0 & 0.79 & 0.56 \\
\hline & RCP8.5 & 0.96 & 0.58 \\
\hline
\end{tabular}

Table 5. Median and standard deviation of flood risk (million USD) between the five GCMs, for each RCP in 2030 and 2050.

\begin{tabular}{|c|c|c|c|c|c|}
\hline & & \multicolumn{2}{|c|}{ Low SLR } & \multicolumn{2}{|c|}{ High SLR } \\
\hline & & Median & $\begin{array}{l}\text { Standard } \\
\text { deviation }\end{array}$ & Median & $\begin{array}{l}\text { Standard } \\
\text { deviation }\end{array}$ \\
\hline \multirow{4}{*}{ હ్లి } & RCP2.6 & 97 & 109 & 124 & 108 \\
\hline & RCP4.5 & 105 & 157 & 133 & 156 \\
\hline & RCP6.0 & 90 & 170 & 117 & 168 \\
\hline & RCP8.5 & 102 & 175 & 130 & 171 \\
\hline \multirow{4}{*}{ 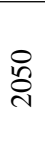 } & RCP2.6 & 129 & 117 & 188 & 114 \\
\hline & RCP4.5 & 141 & 140 & 201 & 138 \\
\hline & RCP6.0 & 130 & 185 & 190 & 182 \\
\hline & RCP8.5 & 226 & 209 & 284 & 206 \\
\hline
\end{tabular}

In 2030, the highest risk values are simulated under RCP6.0 and RCP8.5, whilst there are only small differences between the other RCPs. According to IPCC (2014), the global radiative forcing by 2030 is the highest under RCP8.5. By 2050, we see an increase in the difference between the risk estimates under RCP8.5 and those under the other RCPs.

\subsubsection{Land use change}

As stated earlier, two approaches were used to estimate the influence of land use change. The main one used is the idealized scenario, based on the official Spatial Plan 2030. This represents an idealized situation, in the case that the land use planning envisioned for the coming decades is successfully implemented, rather than a scenario of unplanned development. Assuming this Spatial Plan 2030, and assuming no other changes in physical or socio-economic factors, flood risk would decrease between the baseline situation and 2030 by $12 \%$. More detailed results are presented in Table 6 , which shows the percentage of both the total inundated area and damage associated with each land use class. The results show that the majority of the inundated areas are found in locations with residential land use classes. This is both the case 
Table 6. Percentage of total inundated area and total flood risk found in each land use category. Results are shown here for baseline land use and idealized land use in 2030.

\begin{tabular}{lccccc}
\hline \multirow{2}{*}{ Land use class } & \multicolumn{2}{c}{ Baseline land use } & & \multicolumn{2}{c}{2030 land use } \\
\cline { 2 - 3 } \cline { 5 - 6 } & Inundated area & Flood damage & & Inundated area & Flood damage \\
\cline { 2 - 4 } & 3.1 & 9.7 & 0.0 & 0.1 \\
\hline Government facility & 0.0 & 0.0 & & 0.0 & 0.0 \\
Forestry & 12.4 & 33.3 & & 17.3 & 46.6 \\
Industry and warehouse & 13.2 & 41.8 & & 10.6 & 30.8 \\
Commercial and business & 17.2 & 4.1 & 58.0 & 19.1 \\
Residential & 44.5 & 10.4 & & 1.6 & 1.2 \\
Residential with greenery & 2.4 & 0.0 & & 12.0 & 2.2 \\
Agriculture and open space & 4.9 & 0.1 & 0.5 & 0.1 \\
Swamp river and pond & & & & & \\
\hline
\end{tabular}

under baseline land use (62\%; summation of "High density urban kampung" and "Planned house") and under 2030 land use $(60 \%$; summation of "Residentials" and "Residentials with greenery"). However, the largest share of total damages are found in the land use classes related to commercial areas, i.e. "Industry and warehouse" followed by "Commercial and business". Combined, these two land use classes account for ca. $75 \%$ of total damages under baseline land use, and $77 \%$ under 2030 land use.

To carry out a simple comparison with the potential increase in risk if this idealized land use scenario for 2030 is not achieved, we also used a simple method to extrapolate simulated damages using the 1980, 1995, 2002, and 2009 land use maps to 2030 (see Sect. 2.2). Using this simple approach, flood risk in 2030 (due to land use change alone) is USD 270 million, i.e. an increase of $45 \%$. In reality, we do not know whether the past trend in land use change observed over the period 1980-2009 will continue at the same rate until 2030. Hence, this should be considered as a firstorder estimate, assuming that this trend continues, and that the Spatial Plan is not implemented successfully.

\subsubsection{Land subsidence}

Assuming only an increase in land subsidence for 2030, we found an increase in annual expected damage of $126 \%$ between the baseline and 2030, i.e. an increase from USD 186 to 421 million p.a.

The increase in risk resulting from projected subsidence, however, is not uniform across the city. In Fig. 8, we see the percentage increase in flood damage per grid cell over the period 2010-2030 due to subsidence alone, following the rates of subsidence shown in Fig. 2. Note also that the actual influence of subsidence will strongly depend on the changes in other environmental and socio-economic drivers (as discussed in Sect. 4.3).

\subsection{Impacts of future changes in combined risk drivers on flood risk}

In the previous subsections, the change in risk between the baseline situation and the future scenarios has been shown for each risk driver separately. In reality, the future situation will depend on the combined change of all the drivers. Hence, in this section we show the impacts of combinations of different risk drivers on future risk.

In Fig. 9, we show probability density functions (PDFs) of the simulated annual expected damage, whereby each PDF is derived from a two-parameter gamma distribution fit to the $20 \mathrm{GCM} / \mathrm{RCP}$ combinations. A similar approach was followed by Ward et al. (2014b) for including climate change in probabilistic projections of flood risk along the Rhine in Europe. The dotted black vertical line represents baseline flood risk, i.e. USD 186 million p.a.

Figure 9 clearly shows the strong influence of projected subsidence on the overall change in risk. All of the PDFs representing scenarios with subsidence (shown in red) show much higher annual expected damage than those without subsidence (shown in blue). The PDFs also clearly show the large uncertainty associated with the projected changes in precipitation from the different GCMs and RCPs, which is large under all of the PDFs. However, the results show that if we include land subsidence in the future projections, the probability of future flood risk exceeding baseline flood risk exceeds $99.999 \%$ (when accounting for changes in precipitation).

The results also show the importance of the interaction between different drivers. For example, if we examine the difference between the PDFs for low and high sea level rise, we see a small difference under the scenarios with no subsidence and land use 2030. However, if we make a similar comparison using the scenarios that include subsidence, we see a larger difference between the low and high sea level rise scenarios. Similar differences can be found when comparing the scenarios with and without projected land use change. 


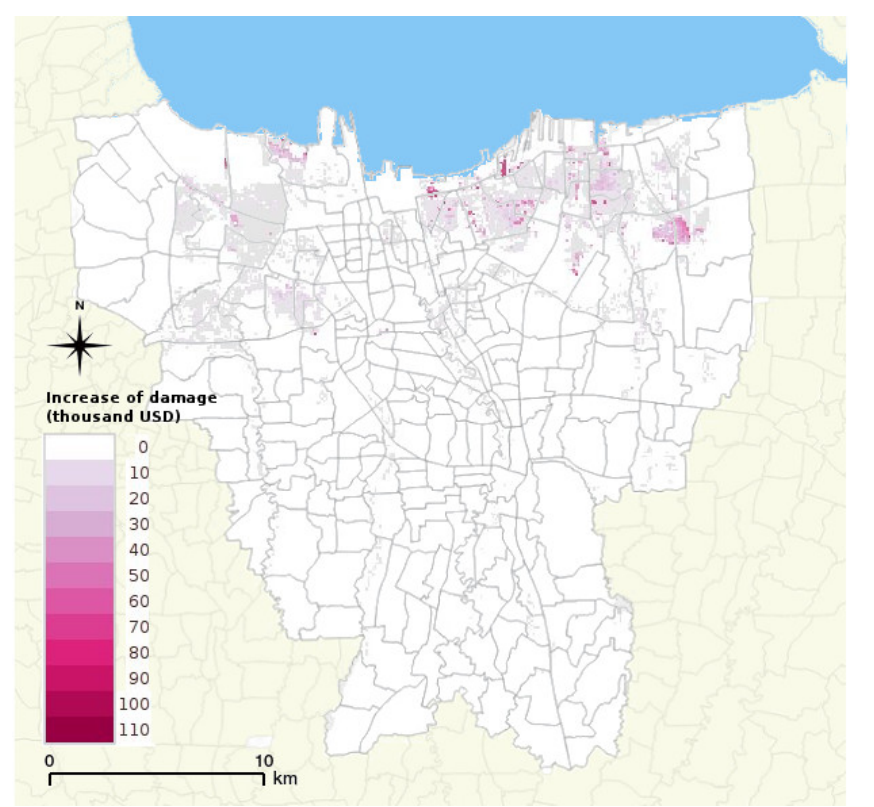

Figure 8. Increase of damage per grid cell at a return period of 100 years between the baseline condition and idealized land use map 2030 due to land subsidence alone.

The differences between the two scenarios are amplified with higher rates of subsidence and/or sea level rise.

From Table 7, we summarize the results of the influence on risk of the individual drivers and the combined scenarios for 2030. For scenarios with climate change, we show both the median and 5th-95th percentile values based on the gamma distributions. From the table, it is clear that land subsidence has the largest influence on future risk, assuming our simple scenario of land subsidence. If the increase in risk due to land use change continues at the rate as over the period 19802009, this has the second highest influence on risk, followed by sea level rise. Given the high range of uncertainty in the influence on risk of future changes in precipitation intensity, the 5th-95th percentiles of this variable span a very large range, from an increase in risk of 104 to a decrease in risk of $94 \%$.

\section{Discussion}

\subsection{Uncertainty in projections of change in precipitation intensity}

In Sect. 3, we showed the impacts of climate change on flood risk, whereby the impacts of climate change are expressed through both sea level rise and changes in the magnitude of extreme 1-day precipitation totals. In terms of the latter, our analyses show this variable to be highly uncertain. Whilst the median projections (Table 4) show a decrease compared to baseline - which results in lower median flood risk in the future when combined with the low sea level rise scenario
(Table 5) - the PDFs in Fig. 9 show that there is deep uncertainty attached to the impacts of changes in precipitation on the risk. Nevertheless, this does not mean that it is not an important factor to consider. In fact, some of the GCM-RCP combinations indicate an increase in risk of a factor greater than 2.4 as a result of climate change alone. It should be noted that here we used all possible combinations of RCPs to represent changes in precipitation intensity and the two sea level rise scenarios (high and low).

The uncertainty in future risk projections is confirmed by other research in the region. For example, rainfall observations across Indonesia as a whole for the second half of the twentieth century suggest that mean annual rainfall may have decreased by ca. 2-3\%, mainly in the wet season from December to February (Boer and Faqih, 2004). Earlier projections of mean annual rainfall over the twenty-first century taken from several climate models suggest that mean annual rainfall may increase in the future across most of Indonesia, although in Java it may decrease (Hulme and Sheard, 1999). Naylor et al. (2007) downscaled output from the Intergovernmental Panel on Climate Change AR4 suite of climate models for the twenty-first century, to the regional level, and found a large uncertainty on the monsoon onset in West Java/Central Java region. Moreover, they found that precipitation totals may decrease (by up to $75 \%$ in the tails) during the dry season, although this research did not address the wet season, when flooding generally occurs in Jakarta. Scoccimarro et al. (2013) investigated potential changes in extreme precipitation events by 2100 using RCP 8.5 and several Coupled Model Intercomparison Project Phase 5 (CMIP5) models. They found that the 90th and 99th percentiles of heavy rainfall may increase during the months June-August in Indonesia. However, this is the dry season, whilst flooding in Jakarta usually occurs during the wet months of DecemberFebruary.

Recently, Chadwick et al. (2013) carried out climate model experiments to assess the potential changes in regional patterns of precipitation and atmospheric circulation resulting from a "ramp-up" of $\mathrm{CO}_{2}$ levels from pre-industrial levels (280 ppm) until quadrupling (1120 ppm) after 70 years (and scenarios of $3 \times \mathrm{CO}_{2}, 2 \times \mathrm{CO}_{2}$, and $1.5 \times \mathrm{CO}_{2}$ ), followed by 10 years of stabilization, and then a 70-year ramp-down to pre-industrial levels. During the ramp-up phase, they found decreased precipitation in the part of the tropical western Pacific where Indonesia is located. Chadwick et al. (2013) suggest that this regional redistribution of rainfall is caused by circulation changes associated with changing gradients of sea-surface temperatures in the tropical Pacific.

Further uncertainties in the future response of precipitation to climate change in the region result from potential changes in the frequency and/or magnitude of El Niño-Southern Oscillation (ENSO). ENSO shows strong linkages with precipitation in parts of the Indonesian archipelago (Aldrian and Susanto, 2003; Aldrian et al., 2007; Hendon, 2003; Qian et al., 2010), and is linked to anomalies in both discharge (Poer- 


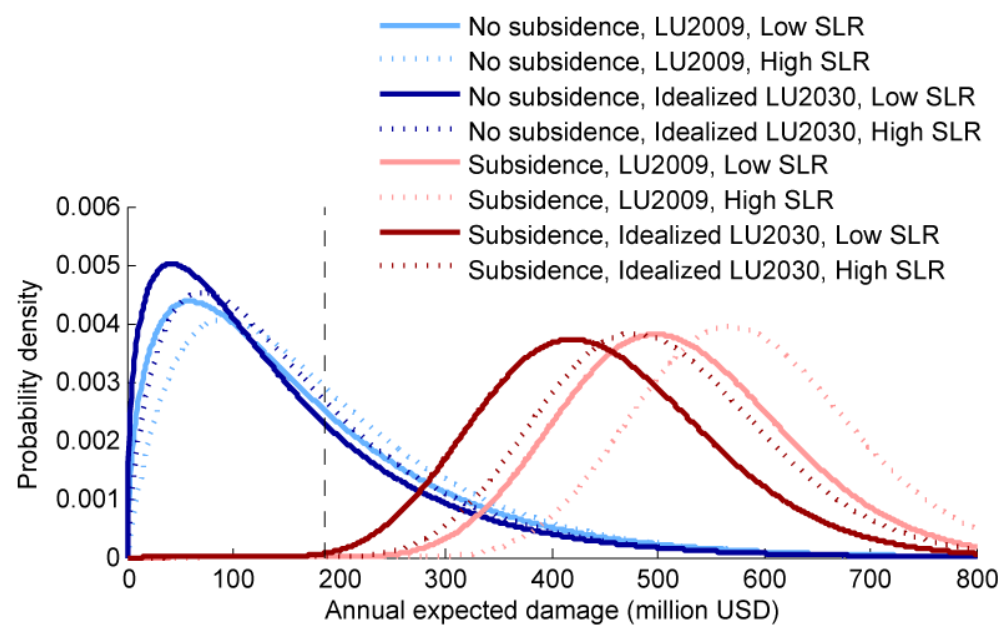

Figure 9. Probability distribution function (PDFs) of future flood risk in Jakarta under different scenarios. The black vertical dashed line shows risk associated with baseline conditions (USD 186 million p.a.). The PDFs are obtained by applying a two-parameter gamma distribution to simulated risk values from five GCMs and four RCP emission scenarios. PDFs are shown for different combinations of the following scenarios: (a) subsidence and no subsidence; (b) land use under baseline conditions (LU2009) and under the idealized land scenario for 2030 (LU2030); and (c) high or low sea level rise (SLR).

Table 7. Flood risk (annual expected damage) in 2030 for different risk drivers, and percentage change in risk compared to baseline conditions. ${ }^{*}$ Using idealized land use scenario for 2030.

\begin{tabular}{lll}
\hline Scenarios & Flood risk (million USD) & Percent change \\
\hline Baseline & 186 & NA \\
Baseline + change of precipitation & 101 (median) & -46 \\
& $11-379(5$ th-95th percentiles) & -94 to +104 \\
Baseline + change of land use (idealized) & 163 & -12 \\
Baseline + change of land use (extrapolation) & 270 & $45 \%$ \\
Baseline + sea level rise & 212 & +14 \\
& $200-224$ & +7 to +20 \\
Baseline + land subsidence & 421 & +126 \\
Baseline + all future changes combined & 521 (median) & +180 \\
& $393-673(5$ th-95th percentiles) & +111 to +262 \\
\hline
\end{tabular}

bandono et al., 2014) and flood volumes (Ward et al., 2014a). The current generation of climate models shows little agreement on whether (and if so how) the frequency of ENSO could change due to climate change (Guilyardi et al., 2009; Paeth et al., 2008; Van Oldenborgh et al., 2005). However, a recent study suggested that extreme El Niño events (which are associated with negative flood anomalies in western Java; Ward et al., 2014a) may become more frequent (Cai et al., 2014).

To account for this large uncertainty, we developed the probabilistic projections of flood risk under climate change shown in Fig. 9. Instead of only describing potential changes in the median flood risk under climate change (a decrease with a low sea level rise scenario and a slight increase with a high sea level rise scenario), these provide much more information, by describing the change in flood risk across the entire distribution of the 20 GCM-RCP combinations (five GCMs $\times$ four RCPs).

\subsection{Relative influence of different drivers on flood risk}

In this section, we discuss the relative influence of the different drivers on the simulated flood risk. As stated in the introduction, this paper is not intended to provide a full uncertainty assessment. For each driver of risk, we used the best available data to develop the future scenarios, meaning that more scenarios are available for some drivers (e.g. climate change) than others (e.g. land subsidence and land use change). Therefore, the results should be interpreted as first-order estimates of the potential order of magnitude of the future changes in risk, and they certainly should not be interpreted as covering the entire uncertainty space.

From Table 7, we see that land subsidence is the single driver with the greatest contribution to increased flood risk 
compared to the baseline, assuming the land subsidence scenario used in this study. If we consider a linear increase from 2013 to 2030 , it equals an annual rate of USD 13.8 million $(7.4 \%)$ p.a. Given an assumption of a $2.5 \mathrm{~cm}$ rate of subsidence p.a. (on average over the whole city), this would mean an increase in risk of USD 5.5 million per cm subsidence. In reality, the rate of land subsidence is geographically heterogeneous, with higher rates in the north of the city. The land subsidence scenario used in this study is of course highly simplistic, but it does give a powerful indication of the order of magnitude of the problem in terms of its impacts on risk. If the government's target of reducing groundwater extraction is not reached, the rate of subsidence could be even higher.

The problem of land subsidence is a serious issue in many other low-lying coastal and delta cities (Syvitski et al., 2009; Erkens et al., 2014; Brown and Nicholls, 2015). Ward et al. (2011b) also showed this driver to be the main factor contributing to projected increases in future coastal flood risk in Jakarta. The annual rate of increase in flood risk due to subsidence calculated for Jakarta is similar to that for Bangkok during the 1990s, which was USD 12 million p.a. (DMR, 2000 in Phien-wej et al., 2006). In Taiwan, the Yunlin area has similar subsidence rates to northern Jakarta, ranging from 3.5 to $14.3 \mathrm{~cm} \mathrm{year}^{-1}$ (Tung and $\mathrm{Hu}, 2012$ ). In this area, high flood damages have also been simulated, for example USD 171 million for a 200-year return period flood.

Using the idealized land use scenario for 2030, we actually found that flood risk could be reduced by $12 \%$ (if all other drivers are kept constant). This shows the huge potential of land use planning to mitigate flood risk, as discussed in Sect. 4.3. On the other hand, using our simple extrapolation of increased risk due to unplanned land use growth, risk could increase by $45 \%$ by 2030 . This is somewhat higher than the increase in risk that we simulated due to sea level rise alone (increase of 7-20\%), but of the same order of magnitude. However, the mechanisms behind these forcings are different, as is the geographical distribution in the change in risk.

Since sea level rise affects river flooding by making discharge of excess waters to the sea more difficult, most of the increase in risk simulated under the sea level rise scenarios is concentrated towards the coastal area. Using the average values across the different sea level rise scenarios, the increase translates to an increase in risk of ca. USD 1.5 million p.a., or USD 2.6 million per cm sea level rise.

On the other hand, the change in risk associated with land use change is distributed more evenly across the city. Finally, Table 7 also shows that the combined impact of all drivers on risk $(+180 \%$ under the median scenario of precipitation change, and assuming the idealized land use scenario for 2030) is much greater than the summation of the impacts of the individual flood drivers.

\subsection{Implications for risk management}

The flood risk problem in Jakarta results from the interplay of a large number of drivers, both physical and socio-economic in nature. Hence, measures and strategies to reduce that risk must be taken in an integrated way (e.g. Jha et al., 2012). The development of such strategies is indeed taking place in Jakarta, a good example being the National Coastal Integrated Coastal Development program. Whilst the most wellknown aspect of this program is the planned "giant sea wall" (over $35 \mathrm{~km}$ long), it also integrates plans to construct and strengthen other defences in the short term, as well as address pressing issues such as land subsidence, water supply, and water sanitation. The program builds on initial findings of the Jakarta Coastal Defence Strategy, 2011; Jeuken et al., 2015).

Clearly, concerted efforts to address the land subsidence issue are paramount to reducing the increasing flood risk in Jakarta, as we have shown the potentially very large influence that land subsidence could have on future river flood risk. The subsidence scenarios used in this study are a simple extrapolation of past trends, and future subsidence rates may turn out to be higher or lower. It has been suggested to target measures for reducing soil water extraction, which is the main cause of land subsidence in Jakarta (Abidin et al., 2011). Soil water extraction takes place both for supplying water for drinking and industry, as well as in the construction of high-rise buildings. PDAM Provinsi DKI Jakarta (2012), the water industry board of Jakarta, supplies water to $61.1 \%$ of consumers in Jakarta. They report that an additional $8-10 \mathrm{~m}^{3} \mathrm{~s}^{-1}$ would be needed to erase the need for all deep wells while sufficing the needs of the rest currently not sufficed. According to a synthesis of results in reports by PAM Lyonaise Jaya (2012) and Aetra Air Jakarta (2014) this would require an investment of ca. USD 389 million. Whilst this is a large investment, it is of the same order of magnitude as our projected increase in risk per annum resulting from land subsidence, land use change, and climate change. Hence, whilst this is a very simplistic example, it shows that the costs of the measures to increase and improve water supply appear to be small in relation to the damages that they could help to avoid, even without factoring in the other benefits. Indeed, strict regulations on groundwater pumping (accompanied by the supply of alternative water sources) have been shown to be effective in reducing land subsidence. For example, the rate of subsidence in Bangkok was ca. $12 \mathrm{~cm}$ year during the $1980 \mathrm{~s}$, but was reduced to $2 \mathrm{~cm}$ year after strict regulations on deep well pumping (Phien-wej et al., 2006). A nested modelling approach by Aichi (2008) has shown that the groundwater regulations in Tokyo have led to decreased subsidence since the mid-1970s. The groundwater regulation was effective for Tokyo and the surrounding three prefectures for 14 years from January 1961 until April 1974 (Tokunaga, 2008). As mentioned earlier, high-rise building construction also extracts water from the soil (dewatering) during the process. This intensive extraction of soil water in 
the short term has been reported to result in severe localized land subsidence (Zhang et al., 2013). Hence, it may also be useful to consider other piling processes, such as auger piling (Abdrabbo and Gaaver, 2012). If dewatering is unavoidable for Jakarta, it may be useful to focus such high-rise development in those parts of the city where the lithology is more compacted, such as in the southern part (Bakr, 2015).

In this study, we represented changes in land use using both an idealized scenario for 2030, in which the official Jakarta Spatial Plan 2030 is fully implemented, and a simple extrapolation of past increases in flood risk due to land use change to the future. Our results show that under the idealized scenario (land use change alone), risk would decrease by $12 \%$, compared to an increase of $45 \%$ using the extrapolation of past trends to the future. Whilst we acknowledge that these should only be considered as first order estimates, these large differences do indicate the large potential of land use planning to mitigate flood risk, especially when combined with other measures. The results for the idealized land use scenario are particularly encouraging, if the plan can be successfully implemented, given the fact that changes in exposure through urban development are seen as one of the main drivers of risk in developing countries (Jongman et al., 2012; UNISDR, 2013). Moreover, the land use plan scenario does not include assumptions on potential measures or strategies that could be taken to further reduce flood risk. For example, in Indonesia as a whole, Muis et al. (2015) simulated increases in both river and coastal flood risk by 2030, assuming a scenario where building is allowed in flood-prone areas, and several scenarios where new buildings are prohibited (with different levels of enforcement) in the 100-year flood zone. They found that river flood risk could be reduced by about $30-60 \%$, and coastal flood risk by about $65-80 \%$, compared to the scenario in 2030 with no building restrictions in the flood-prone zone.

Although we have assumed vulnerability (as represented by the depth-damage functions) to be constant through time, in reality, vulnerability is also temporally variable. For example, Mechler and Bouwer (2014) have shown that vulnerability to flooding in Bangladesh reduced over the last decade, due to early warning systems, flood preparedness, and so forth. Measures are also available to reduce the physical vulnerability to floods, such as dry-proofing and wet-proofing of houses in flood-prone areas (e.g. Kreibich et al., 2005, 2011; Kreibich and Thieken, 2009; Poussin et al., 2012; Thurston et al., 2008). In Jakarta, measures are already being taken at the household level, such as the building of second stories on houses so that valuable possessions can be moved upwards away from flood waters in the event of a flood, and using traditional building methods such as rumah panggung (elevated wooden house that stands on piles) in ways that are more commensurate with flooding (e.g. Marfai et al., 2015; Wijayanti et al., 2015). It would be of interest to assess the decrease in risk that could be achieved throughout the city if such measures were to be implemented on a larger scale, for example through the use of building codes.

\subsection{Limitations and future research developments}

In this study, we have made use of the best available scenarios for each of the drivers of risk. However, this entailed making large assumptions, and the quality of the scenarios differs between the drivers. Given the uncertainty in climate change projections, future development of official tailored climate scenarios for Jakarta (or indeed Indonesia) should be a research priority. Such a set of scenarios would allow for a more consistent modelling of climate impacts, not only in terms of flood risk analysis, but indeed in terms of climate impacts across a full range of hazards and sectors (e.g. Aerts et al., 2014). Moreover, tailored scenarios of land subsidence and land use change, using storylines commensurate with the storylines of the climate change scenarios, would allow for a more consistent assessment of the relative influence of the different driving forces. The development of a dedicated land use model for Jakarta would be an important step forward for future flood risk assessments.

In addition, we have only examined river flood risk, while Jakarta also experiences regular flooding due to coastal and flash flooding. The former has been assessed for Jakarta in Ward et al. (2011b), and Muis et al. (2015) have assessed both river and coastal flood risk at the scale of Indonesia using globally available data sets and models. Nevertheless, the impacts of river and coastal flooding can interact with each other - for example when high tides occur at the same time as extreme discharges - and this interaction should be a priority for future flood risk research, not just in Jakarta, but elsewhere (see, e.g., Keef et al., 2009; Klerk et al., 2015; Svensson and Jones, 2004). To enable an assessment of these interactions, one would need to develop time series of both high river discharge and high sea levels, in order to examine the temporal interactions and joint probabilities between these two variables. However, at present, long time series of simulated sea levels are only available for limited regions (e.g. Haigh et al., 2013), although global modelling efforts may extend this possibility in the future.

In this study, vulnerability is only represented through the use of depth-damage functions. As mentioned earlier, these do not include social vulnerability, which is also an important concept for the overall resilience of a system. Moreover, we assume that vulnerability is constant through time. The overall assessment of future flood risk could be improved through future projections of changes in vulnerability. Very few examples exist in the scientific literature of studies where temporal changes in vulnerability are considered. However, Jongman et al. (2015) recently showed that vulnerability to flooding has been reducing over the last 20-30 years in many developing countries. Hence, it would be useful to try to develop scenarios of potential vulnerability change in the future, and assess how this may affect the overall risk. 
In our future projections, we do not include adaptation measures that could be taken to reduce future risk (other than those measures that are already in place). Research by Muis et al. (2015) at the national scale for Indonesia has shown that the growth in future river and coastal flood risk could be contained to a large degree by increasing protection levels through the building of structural measures such as dikes, and by spatial zoning to limit developments in the most floodprone locations, or at least to make future developments in those zones more commensurate with flooding. Moreover, local research in different parts of Jakarta shows that individual households and communities are already taking smallscale measures to reduce vulnerability, such as building second stories on homes, moving valuable items upstairs during floods, and placing elevated entrances to houses (Marfai et al., 2014). Our model does not account for this kind of autonomous adaptation, although it could be included in the model code in the future.

\section{Concluding remarks}

In this paper, we have extended the river flood risk model for Jakarta, developed by Budiyono et al. (2015), to include projections of flood risk under future scenarios of land subsidence, climate change (sea level rise and changes in extreme precipitation), and land use change. By combining scenarios of different drivers of risk in a simple flood risk model, we have developed a method that can relatively quickly provide first-order estimates of the influence of each of these drivers on overall risk in a quantitative manner. Moreover, in this paper we have developed probabilistic scenarios of the influence of climate change on risk, which allows us to gain a better understanding of the potential future changes than if we only use several climate change scenarios.

Combining all of these scenarios, we find a median increase in flood risk of $183 \%$ in 2030 compared to baseline conditions. This value is based on our median projection for the influence of changes in extreme precipitation on flood risk. However, since we found the influence of climate change on extreme precipitation to be highly uncertain, we also developed probabilistic projections of flood risk by developing PDFs based on 20 GCM-RCP combinations. The resulting increases in risk for the 5th and 95th percentiles are 111 and $262 \%$ respectively (when combined with the other drivers). This shows that whilst the influence of climate change on precipitation intensity in the region may be uncertain, when combined with the other drivers of risk, the increase is always large, and hence adaptation is imperative, irrespective of the chosen climate scenario or projection. This probabilistic approach allows us to include a much wider range of information on the potential impacts of climate change on risk, than assessments based on just one or two scenarios. Unfortunately, the data required to develop such probabilistic scenarios of the other risk drivers are not available at this time, hence developing such scenarios would be a useful research priority.

The single driver with the largest influence on future flood risk is land subsidence $(+126 \%)$. Clearly, addressing this driver could potentially have a large influence on reducing future flood risk. We showed that under an idealized land use scenario for 2030, whereby the official Jakarta Spatial Plan 2030 is fully implemented, flood risk could be reduced by $12 \%$ compared to baseline conditions, if all other driving factors are held at baseline levels. On the other hand, if past trends in risk increase due to land use change continue, flood risk could increase by $45 \%$ by 2030 due to land use change alone. This demonstrates the importance of effective land use planning for flood risk reduction. We show that the largest share of total damages is found in land use classes related to commercial areas; these account for ca. $75 \%$ of total damages under baseline land use and $77 \%$ under the idealized land use scenario for 2030. However, in terms of area affected by flooding, residential areas have a great share. Hence, future efforts to reduce risk must focus on optimal land use planning for both classes.

Acknowledgements. This research was funded by the Dutch research programme Knowledge for Climate and Delta Alliance research project HSINT02a (Jakarta Climate Adaptation Tools), and the Connecting Delta Cities initiative (www.deltacities.com).

Edited by: B. Merz

Reviewed by: two anonymous referees

\section{References}

Abdrabbo, F. M. and Gaaver, K. E.: Installation effects of auger cast-in-place piles, Alexandria Engineering Journal, 51, 281292, doi:10.1016/j.aej.2012.08.001, 2012.

Abidin, H. Z., Andreas, H., Gumilar, I., Fukuda, Y., Pohan, Y. E., and Deguchi, T.: Land subsidence of Jakarta (Indonesia) and its relation with urban development, Nat. Hazards, 59, 1753-1771, doi:10.1007/s11069-011-9866-9, 2011.

Aerts, J. C. J. H., Botzen, W. J. W., Emanuel, K., Lin, N., de Moel, H., and Michel-Kerjan, E. O.: Evaluating flood resilience strategies for coastal megacities, Science, 344, 473-475, doi:10.1126/science.1248222, 2014.

Aetra Air Jakarta: Laporan Tahunan 2013: Konservasi Air Selamatkan Lingkungan, PT Aetra Air Jakarta, Jakarta, 2014.

Aichi, M.: Coupled groundwater flow/deformation modelling for predicting land subsidence, in: Groundwater Management in Asian Cities, edited by: Takizawa, S., Springer Japan, Tokyo, 6, 105-124, doi:10.1007/978-4-431-78399-2_6, 2008.

Aldrian, E. and Dwi Susanto, R.: Identification of three dominant rainfall regions within Indonesia and their relationship to sea surface temperature, Int. J. Climatol., 23, 1435-1452, doi:10.1002/joc.950, 2003.

Aldrian, E., Gates, L. D., and Widodo, F. H.: Seasonal variability of Indonesian rainfall in ECHAM4 simulations and in the re- 
analyses: the role of ENSO, Theor. Appl. Climatol., 87, 41-59, doi:10.1007/s00704-006-0218-8, 2007.

Bakr, M.: Influence of groundwater management on land subsidence in deltas, Springer, Water Resour. Manag., 29, 1541-1555, doi:10.1007/s11269-014-0893-7, 2015.

Bappenas: Laporan Perkiraan Kerusakan dan Kerugian Pasca Bencana Banjir Awal Februari 2007 di Wilayah JABODETABEK (Jakarta, Bogor, Depok, Tangerang, dan Bekasi), Kementrian Negara Perencanaan Pembangunan Nasional (Bappenas), Jakarta, 2007.

Bappenas: National Action Plan for Disaster Risk Reduction 20102012, State Ministry for National Development Planning (Bappenas), National Board for Disaster Management (BNPB), Jakarta, 2010.

Boer, R. and Faqih, A.: Current and Future Rainfall Variability in Indonesia, in: An Integrated Assessment of Climate Change Impacts, Adaptation and Vulnerability in Watershed Areas and Communities in Southeast Asia, Report from AIACC Project No AS21, International START Secretariat, Washington, DC, available at: http://sedac.ciesin.columbia.edu/aiacc/ progress/AS21_Jan04.pdf, last access: 29 April 2015, 2004.

Brown, S. and Nicholls, R. J.: Subsidence and human influences in mega deltas: the case of the GangesBrahmaputra-Meghna, Sci. Total Environ., 527-528, 362-374, doi:10.1016/j.scitotenv.2015.04.124, 2015.

Budiyono, Y., Aerts, J., Brinkman, J., Marfai, M. A., and Ward, P.: Flood risk assessment for delta mega-cities: a case study of Jakarta, Nat. Hazards, 75, 389-413, doi:10.1007/s11069-0141327-9, 2015.

Cai, W., Borlace, S., Lengaigne, M., van Rensch, P., Collins, M., Vecchi, G., Timmermann, A., Santoso, A., McPhaden, M. J., Wu, L., England, M. H., Wang, G., Guilyardi, E., and Jin, F.-F.: Increasing frequency of extreme El Nino events due to greenhouse warming, Nature Climate Change, 4, 111-116, doi:10.1038/nclimate2100, 2014.

Caljouw, M., Nas, P. J. M., and Pratiwo, M.: Flooding in Jakarta?: Towards a blue city with improved water management, Bijdr. Taal-Land-V., 161, 454-484, doi:10.1163/22134379-90003704, 2005.

Chadwick, R., Wu, P., Good, P., and Andrews, T.: Asymmetries in tropical rainfall and circulation patterns in idealised $\mathrm{CO}_{2}$ removal experiments, Clim. Dynam., 40, 295-316, doi:10.1007/s00382-012-1287-2, 2013.

Cutter, S. L. and Finch, C.: Temporal and spatial changes in social vulnerability to natural hazards, P. Natl. Acad. Sci. USA, 105, 2301-2306, doi:10.1073/pnas.0710375105, 2008.

Cutter, S. L., Emrich, C. Y., Morath, D. P., and Dunning, C. M.: Integrating social vulnerability into federal flood risk management planning, Journal of Flood Risk Management, 6, 332-344, doi:10.1111/jfr3.12018, 2013.

Deltares: Hydrodynamics, Rainfall Runoff and Real Time Control: User Manual, Deltares, Delft, 2014.

Deltares, HKV, Puslitbang Sumberdaya Air, Institut Teknologi Bandung, Royal HaskoningDHV, Dinas Pekerjaan Umum Provinsi DKI Jakarta and Balai Besar Wilaya Sungai Ciliwung Cisadane: FMIS: Flood Management Information System: Main Report, Ministry of Public Works, Directorate General of Water Resources, Directorate of Rivers and Coastals, Jakarta, 2012.
Direktorat Jenderal Cipta Karya: Prosedur Operasional Baku (POB): Penyusunan Baseline Data 100-0-100 Program Peningkatan Kualitas Permukiman (P2KP), Kementerian Pekerjaan Umum dan Perumahan Rakyat, Jakarta, Indonesia, 2014.

DTR DKI: Peta tata guna lahan provinsi, DKI, Jakarta, 2007.

Endo, T., Kawashima, S., and Kawai, M.: Historical Review of Development of Land Subsidence and its Cease in Shitamachi Lowland, Tokyo, Journal of the Japan Society of Engineering Geology, 42, 74-87, doi:10.5110/jjseg.42.74, 2001.

Erkens, G., Bucx, T., Dam, R., De Lange, G., and Lambert, J.: Sinking Coastal Cities, EGU General Assembly, Vienna, Austria, 27 April-2 May 2014, EGU2014-14606, 2014.

Gain, A. K., Mojtahed, V., Biscaro, C., Balbi, S., and Giupponi, C.: An integrated approach of flood risk assessment in the eastern part of Dhaka City, Nat. Hazards, 79, 1499-1530, doi:10.1007/s11069-015-1911-7, 2015.

Groumpos, P. P.: Fuzzy Cognitive Maps: Basic Theories and Their Application to Complex Systems, in: Fuzzy Cognitive Maps, edited by: Glykas, M., Springer Berlin Heidelberg, 1-22, doi:10.1007/978-3-642-03220-2_1, 2010.

Guilyardi, E., Wittenberg, A., Fedorov, A., Collins, M., Wang, C., Capotondi, A., van Oldenborgh, G. J., and Stockdale, T.: Understanding El Niño in ocean-atmosphere general circulation models: progress and challenges, B. Am. Meteorol. Soc., 90, 325340, doi:10.1175/2008BAMS2387.1, 2009.

Haigh, I. D., Wijeratne, E. M. S., MacPherson, L. R., Pattiaratchi, C. B., Mason, M. S., Crompton, R. P., and George, S.: Estimating present day extreme water level exceedance probabilities around the coastline of Australia: tides, extra-tropical storm surges and mean sea level, Clim. Dynam., 42, 121-138, doi:10.1007/s00382-012-1652-1, 2013.

Hallegatte, S., Green, C., Nicholls, R. J., and Corfee-Morlot, J.: Future flood losses in major coastal cities, Nature Climate Change, 3, 802-806, doi:10.1038/nclimate1979, 2013.

Hanson, S., Nicholls, R., Ranger, N., Hallegatte, S., Corfee-Morlot, J., Herweijer, C., and Chateau, J.: A global ranking of port cities with high exposure to climate extremes, Climatic Change, 104, 89-111, doi:10.1007/s10584-010-9977-4, 2011.

Hempel, S., Frieler, K., Warszawski, L., Schewe, J., and Piontek, F.: A trend-preserving bias correction - the ISI-MIP approach, Earth Syst. Dynam., 4, 219-236, doi:10.5194/esd-4-219-2013, 2013.

Hendon, H. H.: Indonesian Rainfall Variability: Impacts of ENSO and Local Air-Sea Interaction, J. Climate, 16, 1775-1790, doi:10.1175/1520-0442(2003)016<1775:IRVIOE>2.0.CO;2, 2003.

Hulme, M. and Sheard, N.: Climate Change Scenarios for Indonesia, Climatic Research Unit, Norwich, UK, 1999.

IPCC: Climate Change 2013: The Physical Science Basis. Contribution of Working Group I to the Fifth Assessment Report of the Intergovernmental Panel on Climate Change, edited by: Stocker, T. F., Qin, D., Plattner, G.-K., Tignor, M., Allen, S. K., Boschung, J., Nauels, A., Xia, Y., Bex, V., and Midgley, P. M., Cambridge University Press, Cambridge, United Kingdom and New York, NY, USA, 2013.

IPCC: Summary for policymakers, in: Climate Change 2014: Mitigation of Climate Change, contribution of Working Group III to the Fifth Assessment Report of the Intergovernmental Panel on Climate Change, edited by: Edenhofer, O., PichsMadruga, R., Sokona, Y., Farahani, E., Kadner, S., Seyboth, K., 
Adler, A., Baum, I., Brunner, S., Eickemeier, P., Kriemann, B., Savolainen, J., Schlömer, S., von Stechow, C., Zwickel, T., and Minx, J. C., New York, NY, USA, 2014.

JCDS: Jakarta Coastal Defence Strategy: Agenda, JCDS, Jakarta, Indonesia, 2011.

JJeuken, A., Haasnoot, M., Reeder, T., and Ward, P. J.: Lessons learnt from adaptation planning in four deltas and coastal cities, Journal of Water and Climate Change, 6, 711-728, doi:10.2166/wcc.2014.141, 2015.

Jha, A., Bloch, R., and Lamond, J.: Cities and Flooding: a Guide to Integrated Flood Risk Management for the 21st Century, World Bank, Washington, DC, 2012.

Jongman, B., Ward, P. J., and Aerts, J. C. J. H.: Global exposure to river and coastal flooding: long term trends and changes, Global Environ. Chang., 22, 823-835, doi:10.1016/j.gloenvcha.2012.07.004, 2012.

Jongman, B., Winsemius, H. C., Aerts, J. C. J. H., de Perez, E. C., van Aalst, M. K., Kron, W., and Ward, P. J.: Declining vulnerability to river floods and the global benefits of adaptation, P. Natl. Acad. Sci. USA, 112, E2271-E2280, doi:10.1073/pnas.1414439112, 2015.

Keef, C., Svensson, C., and Tawn, J. A.: Spatial dependence in extreme river flows and precipitation for Great Britain, J. Hydrol., 378, 240-252, doi:10.1016/j.jhydrol.2009.09.026, 2009.

Kementerian Koordinator Bidang Perekonomian: Draft Master Plan Pengembangan Terpadu Pesisir Ibukota Negara (PTPIN), Jakarta, 1 April 2014.

Klerk, W. J., Winsemius, H. C., van Verseveld, W. J., Bakker, A. M. R., and Diermanse, F. L. M.: The co-incidence of storm surges and extreme discharges within the Rhine? Meuse Delta, Environ. Res. Lett., 10, 035005, doi:10.1088/17489326/10/3/035005, 2015.

Kreibich, H. and Thieken, A. H.: Coping with floods in the city of Dresden, Germany, Nat. Hazards, 51, 423-436, 2009.

Kreibich, H., Thieken, A. H., Petrow, Th., Müller, M., and Merz, B.: Flood loss reduction of private households due to building precautionary measures - lessons learned from the Elbe flood in August 2002, Nat. Hazards Earth Syst. Sci., 5, 117-126, doi:10.5194/nhess-5-117-2005, 2005.

Kreibich, H., Christenberger, S., and Schwarze, R.: Economic motivation of households to undertake private precautionary measures against floods, Nat. Hazards Earth Syst. Sci., 11, 309-321, doi:10.5194/nhess-11-309-2011, 2011.

Langbein, W. B.: Annual floods and the partial-duration flood series, EOS T. Am. Geophys. Un., 30, 879-881, doi:10.1029/TR030i006p00879, 1949.

Marfai, M. A., Sekaranom, A. B., and Ward, P.: Community responses and adaptation strategies toward flood hazard in Jakarta, Indonesia, Nat. Hazards, 75, 1127-1144, doi:10.1007/s11069014-1365-3, 2015.

Mechler, R. and Bouwer, L. M.: Understanding trends and projections of disaster losses and climate change: is vulnerability the missing link?, Climatic Change, 133, 23-35, doi:10.1007/s10584-014-1141-0, 2014.

Merz, B., Kreibich, H., Schwarze, R., and Thieken, A.: Review article "Assessment of economic flood damage", Nat. Hazards Earth Syst. Sci., 10, 1697-1724, doi:10.5194/nhess-10-16972010, 2010.
Meyer, V., Haase, D., and Scheuer, S.: Flood risk assessment in european river basins - concept, methods, and challenges exemplified at the Mulde River, Integrated Environmental Assessment and Management, 5, 17-26, doi:10.1897/IEAM_2008031.1, 2009.

Muis, S., Güneralp, B., Jongman, B., Aerts, J. C. J. H., and Ward, P. J.: Flood risk and adaptation strategies in Indonesia: a probabilistic analysis using global data, EGU General Assembly 2015, Vienna, Austria, 12-17 April 2015, EGU2015-1349, 2015.

Naylor, R. L., Battisti, D. S., Vimont, D. J., Falcon, W. P., and Burke, M. B.: Assessing risks of climate variability and climate change for Indonesian rice agriculture, P. Natl. Acad. Sci. USA, 104, 7752-7757, doi:10.1073/pnas.0701825104, 2007.

Noorduyn, J. and Verstappen, H. T.: Purnavarman's River-Works Near Tugu, Bijdr. Taal-Land-V., 128, 298-307, 1972.

Paeth, H., Scholten, A., Friederichs, P., and Hense, A.: Uncertainties in climate change prediction: El Niño-Southern Oscillation and monsoons, Global Planet. Change, 60, 265-288, doi:10.1016/j.gloplacha.2007.03.002, 2008.

PAM Lyonaise Jaya: Annual Report 2011, PAM Lyonaise Jaya, Jakarta, 2012.

PDAM Provinsi DKI Jakarta: Pemenuhan Kebutuhan Air Perpipaan Masyarakat Jakarta, available at: http://bplhd.jakarta.go.id/filing/seminarsdperkotaan2012/ PaparanPAMJAYASeminarBPLHD20November2012-kirim.pdf, last access: 4 May 2015, 2012.

Phien-wej, N., Giao, P. H., and Nutalaya, P.: Land subsidence in Bangkok, Thailand, Eng. Geol., 82, 187-201, doi:10.1016/j.enggeo.2005.10.004, 2006.

Poerbandono, P., Julian, M. M., and Ward, P. J.: Assessment of the effects of climate and land cover changes on river discharge and sediment yield, and an adaptive spatial planning in the Jakarta region, Nat. Hazards, 73, 507-530, doi:10.1007/s11069-014-1083$\mathrm{x}, 2014$.

Poussin, J. K., Bubeck, P., Aerts, J. C. J. H., and Ward, P. J.: Potential of semi-structural and non-structural adaptation strategies to reduce future flood risk: case study for the Meuse, Nat. Hazards Earth Syst. Sci., 12, 3455-3471, doi:10.5194/nhess-123455-2012, 2012.

Rencana Tata Ruang Wilayah 2030: Peraturan Daerah Provinsi Daerah Khusus Ibukota Jakarta Nomor 1 Tahun 2012 tentang Rencana Tata Ruang Wilayah 2030, Jakarta, 2012.

Qian, J.-H., Robertson, A. W., and Moron, V.: Interactions among ENSO, the monsoon, and diurnal cycle in rainfall variability over Java, Indonesia, J. Atmos. Sci., 67, 3509-3524, doi:10.1175/2010JAS3348.1, 2010.

Sagala, S., Lassa, J., Yasaditama, H., and Hudalah, D.: The Evolution of Risk and Vulnerability in Greater Jakarta: Contesting Government Policy in Dealing with a Megacity's Exposure to Flooding, An Academic Response to Jakarta Floods in January 2013, IRGSC Working Paper No. 2, Institute of Resource Governance and Social Change (IRGSC), Kupang, 1-18, 2013.

Scoccimarro, E., Gualdi, S., Bellucci, A., Zampieri, M., and Navarra, A.: Heavy precipitation events in a warmer climate: results from CMIP5 models, J. Climate, 26, 7902-7911, doi:10.1175/JCLI-D-12-00850.1, 2013.

Stach, W., Kurgan, L., and Pedrycz, W.: Expert-Based and Computational Methods for Developing Fuzzy Cognitive Maps, in: 
Fuzzy Cognitive Maps, edited by: Glykas, M., Springer Berlin Heidelberg, 23-41, doi:10.1007/978-3-642-03220-2_2, 2010.

Steinberg, F.: Jakarta: environmental problems and sustainability, Habitat Int., 31, 354-365, doi:10.1016/j.habitatint.2007.06.002, 2007.

Svensson, C. and Jones, D. A.: Dependence between sea surge, river flow and precipitation in south and west Britain, Hydrol. Earth Syst. Sci., 8, 973-992, doi:10.5194/hess-8-973-2004, 2004.

Syvitski, J. P. M., Kettner, A. 'J., Overeem, I., Hutton, E. W. H., Hannon, M. T., Brakenridge, G. R., Day, J., Vörösmarty, C., Saito, Y., Giosan, L., and Nicholls, R. J.: Sinking deltas due to human activities, Nat. Geosci., 2, 681-686, doi:10.1038/ngeo629, 2009.

Texier, P.: Floods in Jakarta: when the extreme reveals daily structural constraints and mismanagement, Disaster Prevention and Management, 17, 358-372, doi:10.1108/09653560810887284, 2008.

Thurston, N., Finlinson, B., Breakspear, R., Williams, N., Shaw, J., and Chatterton, J.: Developing the Evidence Base for Flood Resistance and Resilience, R\&D Summary Report, Joint Defra/EA Flood and Coastal Erosion, London, 2008.

Tokunaga, T.: Groundwater potential in the central district of Tokyo, in: Groundwater Management in Asian Cities, edited by: Takizawa, S., Springer Japan, Tokyo, 61-78, doi:10.1007/978-4431-78399-2_4, 2008.

Tollenaar, D., Vatvani, D., Brinkman, J. J., and Bons, K.: NCICD - MP: behoeftespecificatie FHM and JCDS basics and specifications, Deltares, Jakarta, 2013.

Tung, H. and Hu, J.-C.: Assessments of serious anthropogenic land subsidence in Yunlin County of central Taiwan from 1996 to 1999 by Persistent Scatterers InSAR, Tectonophysics, 578, 126135, doi:10.1016/j.tecto.2012.08.009, 2012.

UNISDR: Global Assessment Report on Disaster Risk Reduction 2011: Revealing Risk, Redefining Development, United Nations International Strategy for Disaster Reduction Secretariat, Geneva, 2011.

UNISDR: Global Assessment Report 2013, UNISDR, Geneva, 2013.

van Oldenborgh, G. J., Philip, S. Y., and Collins, M: El Niño in a changing climate: a multi-model study, Ocean Sci., 1, 81-95, doi:10.5194/os-1-81-2005, 2005.

Ward, P. J., de Moel, H., and Aerts, J. C. J. H.: How are flood risk estimates affected by the choice of return-periods?, Nat. Hazards Earth Syst. Sci., 11, 3181-3195, doi:10.5194/nhess-113181-2011, 2011a.
Ward, P. J., Marfai, M. A., Yulianto, F., Hizbaron, D. R., and Aerts, J. C. J. H.: Coastal inundation and damage exposure estimation: a case study for Jakarta, Nat. Hazards, 56, 899-916, doi:10.1007/s11069-010-9599-1, 2011b.

Ward, P. J., Budiyono, Y., and Marfai, M. A.: Flood risk in Jakarta, in: Severe Weather in Eastern Asia, Perils, Risks, Insurance (Munich Re Knowledge Series Natural Hazards), edited by: Munich Re, Munich Re, Munich, Germany, 106-107, 2013a.

Ward, P. J., Pauw, W. P., van Buuren, M. W., and Marfai, M. A.: Governance of flood risk management in a time of climate change: the cases of Jakarta and Rotterdam, Environ. Polit., 22, 518-536, doi:10.1080/09644016.2012.683155, 2013b.

Ward, P. J., Jongman, B., Kummu, M., Dettinger, M. D., Weiland, F. C. S., and Winsemius, H. C.: Strong influence of El Niño Southern Oscillation on flood risk around the world, P. Natl. Acad. Sci. USA, 111, 15659-15664, doi:10.1073/pnas.1409822111, 2014a.

Ward, P. J., van Pelt, S. C., de Keizer, O., Aerts, J. C. J. H., Beersma, J. J., van den Hurk, B. J. J. M., and te Linde, A. H.: Including climate change projections in probabilistic flood risk assessment, Journal of Flood Risk Management, 7, 141-151, doi:10.1111/jfr3.12029, 2014b.

Weedon, G. P., Gomes, S., Viterbo, P., Shuttleworth, W. J., Blyth, E., Österle, H., Adam, J. C., Bellouin, N., Boucher, O., and Best, M.: Creation of the WATCH forcing data and its use to assess global and regional reference crop evaporation over land during the twentieth century, J. Hydrometeorol., 12, 823-848, doi:10.1175/2011JHM1369.1, 2011.

Wijayanti, P., Tono, T., Hastuti, H., and Pramudita, D.: Estimation of River Flood Damage in Jakarta: the Case of Pesanggrahan River, Economy and Environment Program for Southeast Asia (EEPSEA), Penang, available at: http://www.eepsea.org/ o-k2/view-item/id-493/Itemid-192/ (last access: 13 May 2015), 2015.

Winsemius, H. C., Van Beek, L. P. H., Jongman, B., Ward, P. J., and Bouwman, A.: A framework for global river flood risk assessments, Hydrol. Earth Syst. Sci., 17, 1871-1892, doi:10.5194/hess-17-1871-2013, 2013.

Zhang, D., Song, C., and Chen, L.: Numerical evaluation of land subsidence induced by dewatering in deep foundation pit, Journal of Shanghai Jiaotong University (Science), 18, 278-283, doi:10.1007/s12204-013-1394-1, 2013. 